\title{
EKSTRAKSI FITUR AKSARA BALI MENGGUNAKAN METODE ZONING
}

\author{
I Wayan Agus Surya Darma ${ }^{1}$, I Ketut Gede Darma Putra ${ }^{2}$, Made Sudarma ${ }^{3}$
}

\begin{abstract}
Feature extraction is an important process in character recognition system. The purpose of this process is to obtain special feature from a character image. This paper is focuses on how to obtain special feature from a handwritten Balinese character image using zoning. This algorithm dividing Balinese character image into multiple regions, then a special feature on each region resulting the data extracted feature. The test result in this paper generates a various semantic and direction feature data. This is because this paper using handwritten Balinese character. Furthermore, the features that produced in this paper can be used on Balinese character image recognition process.
\end{abstract}

Intisari - Ekstraksi fitur adalah tahap yang penting pada sistem pengenalan karakter. Proses ini dilakukan untuk mendapatkan ciri khusus yang dimiliki oleh citra karakter. Paper ini membahas tentang bagaimana mendapatkan ciri khusus yang dimiliki oleh citra karakter Aksara Bali tulisan tangan (handwritten) menggunakan metode zoning. Metode zoning membagi citra karakter Aksara Bali menjadi beberapa wilayah, kemudian ciri khusus pada setiap wilayah diekstraksi sehingga menghasilkan data fitur. Hasil uji coba pada paper ini menghasilkan data fitur semantik dan fitur arah yang dimiliki oleh Aksara Bali memiliki variasi nilai fitur. Hal ini disebabkan data Aksara yang digunakan pada paper ini adalah Aksara Bali tulisan tangan (handwritten). Selanjutnya, fitur yang dihasilkan pada paper ini dapat digunakan pada proses pengenalan citra karakter Aksara Bali.

Kata kunci: Feature extraction, character, Balinese character, zoning, feature.

\section{PENDAHULUAN}

Sebuah kebudayaan yang ada pada setiap daerah adalah warisan dari nenek moyang serta leluhur yang hendaknya dijaga dan dilestarikan. Ada berbagai macam warisan budaya yang ada di Bali yang perlu mendapatkan perhatian karena mulai tersisihkan karena perkembangan zaman dan teknologi yang semakin maju. Aksara Bali adalah salah satu warisan yang sangat bernilai karena mengandung nilai-nilai budaya masyarakat di Bali.

1 Mahasiswa, Magister Teknik Elektro dan Komputer Universitas Udayana, Kampus Sudirman, Denpasar Bali. Tel. 0361239599, fax:0361239599; e-mail: suryarav@gmail.com

${ }^{2}$ Dosen Teknologi Informmasi Universitas Udayana, Kampus Bukit Jimbaran, Badung, Bali,E-mail:duglair@yahoo.com

${ }^{3}$ Dosen Magister Teknik Elektro dan Komputer Universitas Udayana, Kampus Sudirman, Denpasar Bali. Tel. 0361239599, fax:0361239599,e-mail: debronxs@yahoo.co.id
Aksara Bali memiliki fitur-fitur unik yang dapat membedakan antara satu karakter Aksara Bali dengan karakter lainnya. Fitur ini digunakan pada proses pengenalan Aksara Bali. Fitur-fitur Aksara Bali ini dapat diperoleh dengan proses ekstraksi fitur. Ekstraksi fitur adalah proses yang dilakukan untuk mengetahui pola atau fitur yang dimiliki oleh suatu karakter. Ekstraksi Fitur adalah aspek yang sangat penting pada pengenalan karakter.

Metode zoning adalah teknik yang digunakan untuk mendapatkan fitur yang dimiliki oleh karakter [1]. Pemilihan metode zoning pada paper ini dikarenakan metode ini mampu menghasilkan fitur yang bervariasi karena metode ini membagi citra karakter menjadi beberapa wilayah, sehingga fitur yang terdapat di setiap wilayah akan diekstraksi sehingga menghasilkan fitur karakter yang dapat digunakan pada tahap pengenalan. Fitur ini diperoleh berdasarkan bentuk atau pola yang dimiliki oleh karakter. Berdasarkan beberapa paper berikut ini, metode zoning mampu menghasilkan fitur yang dapat menunjang akurasi pengenalan yang baik.

Paper mengenai ekstraksi fitur pernah ada tentang ekstraksi fitur pada tulisan tangan angka Kanada menggunakan metode zoning [2]. Pada paper tersebut, proses ekstraksi fitur dilakukan pada karakter angka Kanada tulisan tangan (handwritten). Citra angka Kanada dibagi menjadi beberapa wilayah. Sehingga setiap wilayah menghasilkan fitur angka Kanada. Paper serupa lainnya membahas tentang ekstraksi fitur pada karakter angka di India Selatan [3]. Paper ini mengimplementasikan metode ekstraksi zoning pada karakter angka India Selatan yang bervariasi dari segi gaya tulisan tangan (handwritten). Paper lainnya yang yaitu ekstraksi fitur pada karakter Gurmukhi [4]. Paper tersebut memaparkan proses ekstraksi fitur pada karakter Gurmukhi, dengan membagi wilayah berdasarkan image centroid zone dan zone centroid zone.

Sulitnya membaca Aksara Bali menjadi penyebab masyarakat modern tidak ingin mempelajari Aksara Bali. Sehingga Aksara Bali sudah mulai dilupakan oleh masyarakat di Bali khususnya. Oleh karena itu, Aksara Bali perlu untuk dilestarikan dengan cara melakukan digitalisasi pada Aksara Bali untuk mendapatkan fitur-fitur yang dimiliki oleh karakter Aksara Bali. Berdasarkan permasalahan tersebut, ditunjang dengan paper yang telah disebutkan, penulis melakukan penelitian mengenai ekstraksi fitur pada citra Aksara Bali tulisan tangan (handwritten) menggunakan metode zoning untuk mendapatkan fitur-fitur yang terdapat pada karakter Aksara Bali. 


\section{AKSARA BALI}

Aksara Bali adalah salah satu warisan yang sangat bernilai karena mengandung nilai-nilai budaya masyarakat di Bali. Aksara Bali terdiri dari Aksara Wianjana, Aksara Suara, Pengangge dan Angka.

Berikut ini adalah contoh Aksara Wianjana yang terdiri dari 18 karakter.

Tabel 1. Aksara Wianjana

\begin{tabular}{|c|c|c|c|c|c|}
\hline $\mathrm{Ha}$ & $\mathrm{Na}$ & $\mathrm{Ca}$ & $R a$ & $K a$ & $D a$ \\
\hline M & 20 & 25 & $\bigcap$ & 201 & 26 \\
\hline$T a$ & $S a$ & $W a$ & $L a$ & $M a$ & $G a$ \\
\hline Un & 21 & $2 \pi$ & ne & El & ( ) \\
\hline$B a$ & $\mathrm{Nga}$ & $P a$ & $J a$ & $Y a$ & Nya \\
\hline$r n$ & $n$ & $U$ & $\Re$ & Wh & $m$ \\
\hline
\end{tabular}

Data Akasara yang digunakan adalah citra karakter Aksara Bali tulisan tangan (handwritten). Karakter tulisan tangan tidak seperti karakter cetak yang penulisannya akan tetap sama atau konsisten ntuk jenis Aksara Bali yang sama, karena karakter tulisan tangan memungkinkan adanya perbedaan pola lekukan pada penulisan jenis karakter Aksara Bali yang sama, sehingga memungkinkan adanya sedikit perbedaan pada fitur yang dihasilkan pada jenis karakter yang sama.

\section{EKSTRAKSI FITUR}

Ekstraksi fitur adalah proses yang dilakukan untuk mendapatkan ciri khusus yang dimiliki oleh sebuah karakter. Proses ini berguna untuk mengenali sebuah karakter pada sistem pengenalan karakter [5].

Secara umum karakter memiliki 3 ciri diantaranya:

1. Ukuran lebar dan tinggi

Ukuran lebar dan tinggi karakter merupakan ciri pada karakter berdasarkan panjang dan tinggi karakter.

2. Bagian karakter

Merupakan ciri karakter berdasarkan berdasarkan pembagian arean karakter, misalkan bagian atas, bagian tengah dan bagian bawah.

3. Pemodelan stroke

Merupakan ciri yang dimiliki oleh karakter berdasarkan pola lekukan bentuk karakter.

Berdasarkan ciri umum yang dimiliki oleh karakter diatas, proses ekstraksi fitur menghasilkan data fitur yang unik untuk setiap karakter, hal ini berguna pada tahap pengenalan karakter pada sistem pengenalan karakter.

Metode zoning adalah sebuah metode ekstraksi fitur yang dilakukan dengan membagi citra karakter menjadi wilayah tertentu. Pemilihan metode zoning pada paper ini karena metode ini dapat menghasilkan variasi fitur yang beragam karena setiap wilayah akan dicari ciri yang akan menjadi fitur karakter berdasarkan ciri-ciri yang dimiliki oleh karakter itu sendiri. Berikut ini adalah contoh penerapan zoning pada ekstraksi fitur titik henti.

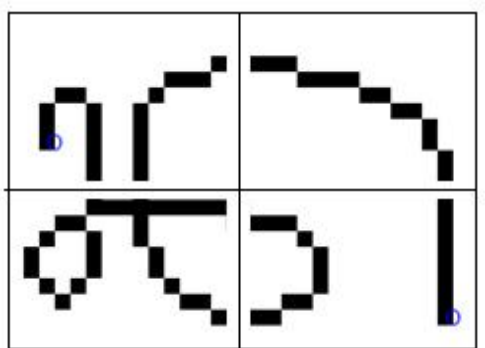

Gambar 1. Pembagian wilayah ekstraksi fitur zoning

Gambar 1 menunjukkan pembagian wilayah citra karakter Aksara Bali menjadi 4 wilayah yaitu, kiri atas, kanan atas, kiri bawah dan kanan bawah. Sehingga meghasilkan fitur titik henti untuk masing-masing wilayah pada karakter Aksara Bali.

\section{METODE}

\section{Fitur Arah}

Fitur arah adalah salah satu fitur yang bisa diperoleh dari karakter Aksara Bali. Fitur arah mendeteksi pola sebuah karakter kemudian pola yang telah didapat diberikan nilai fitur. Fitur arah memiliki orientasi arah sebuah pola yang dibentuk oleh karakter Aksara Bali, sehingga sangat berpengaruh untuk membedakan karakter satu dengan karakter lainnya.

Proses untuk mendapatkan fitur arah, dengan mendeteksi piksel karakter Aksara Bali. Piksel putih diberikan nilai 0 , sedangkan piksel hitam yang membentuk karakter diberikan nilai sesuai dengan orientasi arah dengan ketentuan sebagai berikut.

Tabel 2. Nilai arah

\begin{tabular}{|c|c|c|}
\hline Bentuk & Nilai & Arah \\
\hline & 2 & Vetikal \\
\hline & 4 & Horizontal \\
\hline & 3 & $\begin{array}{c}\text { Diagonal } \\
\text { Kanan }\end{array}$ \\
\hline
\end{tabular}

Tahapan untuk memberikan nilai arah dari suatu karakter Aksara Bali adalah sebagai berikut:

a. Menentukan Titik Awal Karakter

Penentuan titik awal karakter dapat ditemukan pada citra karakter dengan posisi paling bawah dan paling kiri. Piksel yang memiliki segmen garis yang berbeda dari segmen garis sebelumnya merupakan titik awal untuk nilai arah berikutnya. Proses ini menggunakan proses iterasi. Iterasi dilakukan 
hingga semua piksel hitam memiliki nilai arah masing-masing. Semua piksel yang telah ditemukan kemudian diberikan nilai 8, nilai ini bersifat sementara karena akan melalui proses normalisasi.

\section{b. Normalisasi Nilai Arah}

Proses normalisasi dilakukan untuk mengubah nilai sementara yang telah didapat dengan nilai arah yang sesuai dengan ketentuan fitur arah. Proses ini melalui dua tahapan. Tahap pertama adalah pencarian frekuensi terbesar untuk kemunculan nilai arah pada suatu segmen garis yang dimulai dari titik awal. Tahap kedua yaitu menggunakan nilai arah yang memiliki frekuensi kemunculan tertinggi untuk menggantikan nilai sementara pada piksel tersebut.

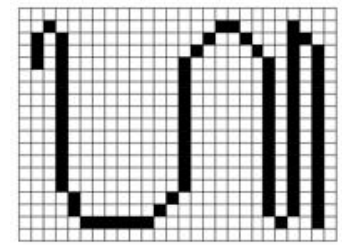

(a)

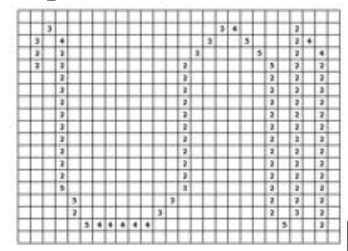

(b)
Gambar 2. Proses pembentukan nilai (a) gambar karakter tulisan Bali (b) hasil pemberian nilai tiap vector

Fitur arah yang telah berhasil didapatkan dibuatkan matriks dengan ukuran 16x1. Matriks tersebut berisikan fitur arah di setiap wilayah citra, pada proses ini metode zoning diimplementasikan dengan membagi citra karakter Aksara Bali menjadi empat wilayah yaitu: kiri atas, kanan atas, kiri bawah dan kanan bawah. Sehingga fitur yang diperoleh untuk setiap wilayah adalah Jumlah vertikal pada kiri atas, diagonal kanan pada kiri atas, horisontal pada kiri atas, diagonal kiri pada kiri atas, vertikal pada kanan atas, diagonal kanan pada kanan atas, horizontal pada kanan atas, diagonal kiri pada kanan atas, vertikal pada kiri bawah, diagonal kanan pada kiri bawah, horizontal pada kiri bawah, diagonal kiri pada kiri bawah, vertikal pada kanan bawah, diagonal kanan pada kanan bawah, horisontal pada kanan bawah, diagonal kiri pada kanan bawah, seperti pada tabel dibawah ini.

Tabel 3. Fitur arah

\begin{tabular}{|c|c|c|c|c|c|c|c|c|c|c|c|c|c|c|c|}
\hline \multicolumn{110}{|c|}{ FITUR ARAH } \\
\hline $\mathbf{1}$ & $\mathbf{2}$ & $\mathbf{3}$ & $\mathbf{4}$ & $\mathbf{5}$ & $\mathbf{6}$ & $\mathbf{7}$ & $\mathbf{8}$ & $\mathbf{9}$ & $\mathbf{1 0}$ & $\mathbf{1 1}$ & $\mathbf{1 2}$ & $\mathbf{1 3}$ & $\mathbf{1 4}$ & $\mathbf{1 5}$ & $\mathbf{1 6}$ \\
\hline 6 & 2 & 1 & 2 & 5 & 2 & 8 & 8 & 16 & 7 & 11 & 7 & 15 & 6 & 0 & 4 \\
\hline 7 & 6 & 0 & 5 & 6 & 4 & 7 & 8 & 9 & 9 & 2 & 11 & 23 & 13 & 1 & 3 \\
\hline 7 & 4 & 2 & 2 & 5 & 8 & 3 & 9 & 16 & 13 & 3 & 9 & 15 & 4 & 0 & 2 \\
\hline 3 & 10 & 0 & 4 & 4 & 8 & 6 & 10 & 23 & 9 & 5 & 8 & 23 & 4 & 0 & 6 \\
\hline 3 & 0 & 2 & 6 & 7 & 0 & 12 & 7 & 23 & 8 & 3 & 7 & 23 & 7 & 0 & 6 \\
\hline 18 & 9 & 3 & 10 & 8 & 17 & 2 & 17 & 14 & 12 & 6 & 7 & 9 & 8 & 7 & 15 \\
\hline 11 & 16 & 0 & 6 & 1 & 20 & 10 & 19 & 7 & 3 & 11 & 11 & 13 & 4 & 8 & 13 \\
\hline 13 & 7 & 3 & 10 & 13 & 24 & 7 & 9 & 6 & 11 & 5 & 12 & 15 & 10 & 7 & 19 \\
\hline 9 & 7 & 3 & 11 & 8 & 18 & 6 & 14 & 4 & 10 & 6 & 11 & 14 & 7 & 3 & 11 \\
\hline
\end{tabular}

\section{Fitur Semantik}

Fitur semantik adalah sebuah fitur yang dihasilkan berdasarkan ciri-ciri semantik yang dimiliki oleh karakter Aksara Bali. Ciri semantik tersebut diantaranya jumlah stroke hitam, loop, titik akhir, panjang karakter, lebar karakter maupun titik awal karakter. Berikut ini adalah fitur semantik yang dimiliki oleh karakter Aksara Bali.
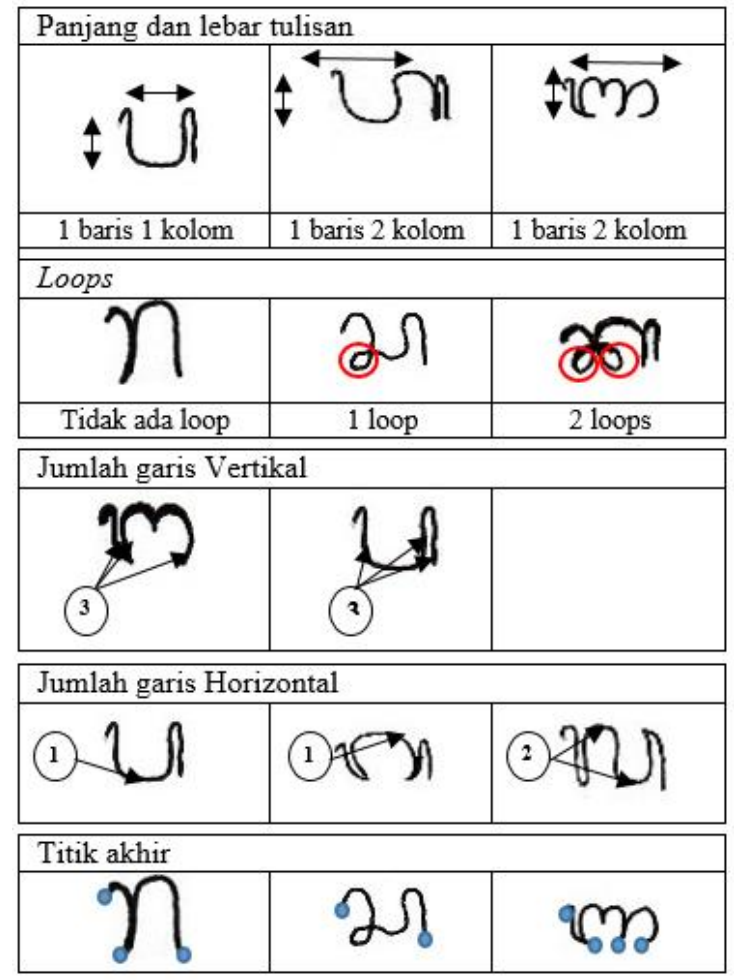

Gambar 3. Informasi Semantik Pada Karakter Aksara Bali

Metode zoning diimplementasikan pada citra karakter Aksara Bali dengan membagi wilayah citra Aksara Bali sehingga fitur semantik dihasilkan pada setiap wilayah yang telah dibagi dimasukkan pada matriks dengan ukuran $12 \times 1$ untuk masing-masing karakter.

Tabel 4. Fitur Semantik

\begin{tabular}{|c|c|c|c|c|c|c|c|c|c|c|c|}
\hline \multicolumn{10}{|c|}{ FITUR SEMANTIK } \\
\hline $\mathbf{1}$ & $\mathbf{2}$ & $\mathbf{3}$ & $\mathbf{4}$ & $\mathbf{5}$ & $\mathbf{6}$ & $\mathbf{7}$ & $\mathbf{8}$ & $\mathbf{9}$ & $\mathbf{1 0}$ & $\mathbf{1 1}$ & $\mathbf{1 2}$ \\
\hline 3 & 1 & 0 & 0 & 2 & 2 & 1 & 0 & 2 & 4 & 1 & 3 \\
\hline 4 & 1 & 1 & 0 & 2 & 2 & 1 & 0 & 1 & 3 & 1 & 2 \\
\hline 4 & 1 & 1 & 0 & 2 & 2 & 1 & 0 & 0 & 3 & 1 & 2 \\
\hline 3 & 1 & 0 & 0 & 2 & 2 & 1 & 0 & 2 & 3 & 0 & 3 \\
\hline 3 & 1 & 0 & 0 & 2 & 2 & 1 & 0 & 1 & 4 & 1 & 3 \\
\hline
\end{tabular}

\section{HASIL DAN PEMBAHASAN}

A. Hasil

Ekstraksi fitur pada citra karakter Aksara Bali menggunakan metode zoning menghasilkan fitur arah dan 
fitur semantik.Citra Aksara Bali yang digunakan adalah karakter Aksara Bali tulisan tangan (handwritten). Data fitur Aksara Bali dapat dilihat pada hasil ekstraksi fitur pada Aksara Bali " $\mathrm{Ka}$ ” berikut ini.

Tabel 5. Fitur Semantik dan Fitur Arah Aksara Bali " $\mathrm{Ka}$ "

\begin{tabular}{|c|c|c|}
\hline $\begin{array}{c}\text { Aksara } \\
\text { Bali }\end{array}$ & Jenis Fitur & Nilai \\
\hline & Jumlah vertikal pada kiri atas & 17 \\
\hline & Jumlah diagonal kanan pada kiri atas & 15 \\
\hline & Jumlah horisontal pada kiri atas & 3 \\
\hline & Jumlah diagonal kiri pada kiri atas & 3 \\
\hline & Jumlah vertikal pada kanan atas & 9 \\
\hline & Jumlah diagonal kanan pada kanan atas & 17 \\
\hline & Jumlah horizontal pada kanan atas & 7 \\
\hline & Jumlah diagonal kiri pada kanan atas & 28 \\
\hline & Jumlah vertikal pada kiri bawah & 16 \\
\hline & Jumlah diagonal kanan pada kiri bawah & 8 \\
\hline & Jumlah horis ontalpada kiri bawah & 3 \\
\hline & Jumlah diagonal kiri pada kiri bawah & 13 \\
\hline & Jumlah vertikal pada kanan bawah & 16 \\
\hline & Jumlah diagonal kanan pada kanan bawah & 10 \\
\hline & Jumlah horisontal pada kanan bawah & 3 \\
\hline & Jumlah diagonal kiri pada kanan bawah & 10 \\
\hline & Jumlah titik henti & 4 \\
\hline & Jumlah titik henti pada zona kiri atas & 1 \\
\hline & Jumlah titik henti pada zona kanan atas & 0 \\
\hline & Jumlah titik henti pada zona kiri bawah & 1 \\
\hline & Jumlah titik henti pada zona kanan bawah & 2 \\
\hline & Jumlah panjang karakter & 2 \\
\hline & Jumlah lebar karakter & 1 \\
\hline & Jumlah loop & 2 \\
\hline & Jumlah horisontal & 1 \\
\hline & Jumlah vertikal & 4 \\
\hline & Jumlah vertikal pada zona kiri & 2 \\
\hline & Jumlah vertikal pada zona kanan & 2 \\
\hline
\end{tabular}

Jumlah keseluruhan fitur yang dihasilkan pada proses ekstraksi fitur karakter Aksara Bali adalah 28, seperti pada gambar 5. Fitur Aksara Bali yang telah berhasil didapat pada citra Karakter Aksara Bali disimpan dalam sebuah matriks dengan ukuran 28x1 untuk masing-masing karakter Aksara Bali.

\section{B. Pembahasan}

Ekstraksi fitur menggunakan metode zoning merupakan proses ekstraksi fitur berdasarkan wilayah citra karakter Aksara Bali. Sehingga fitur arah dan fitur semantik yang dimiliki oleh karakter Aksara Bali bisa didapatkan pada masing-masing wilayah tersebut. Berikut ini adalah rincian fitur yang berhasil didapatkan pada Aksara Bali.

\section{Fitur Semantik}

Berikut ini adalah fitur semantik yang diperoleh dari karakter Aksara Bali.

\subsection{Titik henti}

Fitur titik henti yang diperoleh dari Aksara Bali adalah titik henti pada zona kiri atas, kanan atas, kiri bawah dan kanan bawah.

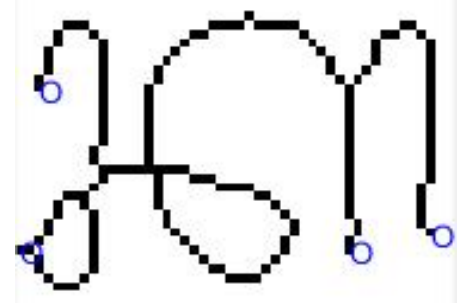

Gambar 4. Titik Henti pada Aksara Bali "KA"

Berikut ini adalah nilai fitur titik henti yang didapatkan pada masing-masing wilayah.

\subsection{Loop}

Fitur semantik berikutnya adalah Loop, dimana fitur ini diperoleh pada Aksara Bali yang memiliki pola lintasan pada penulisannya. Berikut ini adalah fitur loop yang diperoleh dari aksara " $\mathrm{Ka}$ ".

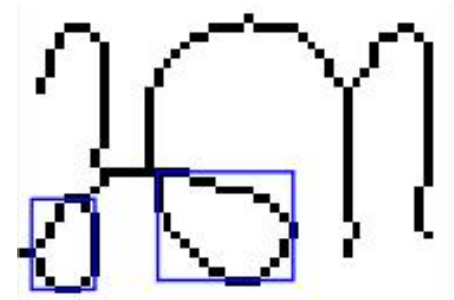

Gambar 5. Loop pada Aksara Bali "KA”

\subsection{Panjang dan Lebar Karakter}

Fitur semantik lainnya yang dihasilkan adalah panjang dan lebar karakter Aksara Bali. Fitur panjang dan lebar karakter bali ini menghitung jumlah baris dan kolom, lebar Aksara Bali dianggap sebagai satu baris. Jika lebar kolom karakter lebih panjang dari lebar baris maka lebar kolom dianggap dua. Berikut ini hasil fitur panjang dan lebar karakter yang dihasikan dari Aksara Bali " $K a$ ".

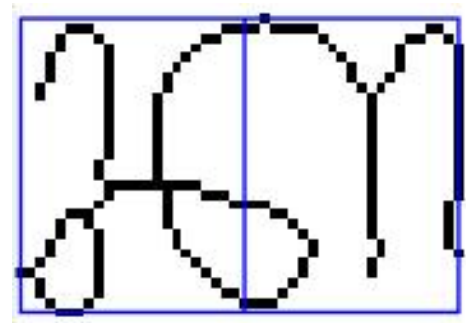

Gambar 6. Panjang dan Lebar Karakter Aksara Bali "KA"

\subsection{Garis Vertikal}

Garis vertikal pada Aksara Bali merupakan fitur yang dihasilkan berdasarkan fitur semantik. Fitur ini diperoleh dengan mencari garis vertikal pada Aksara Bali. Berikut ini adalah hasil fitur garis vertikal yang diperoleh pada Aksara Bali " $\mathrm{Ka}$ ". 


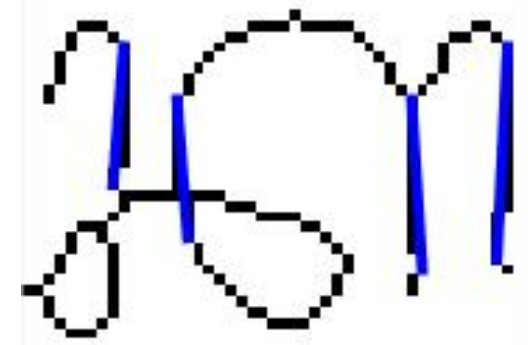

Gambar 7. Garis Vertikal Pada Aksara Bali "KA"

\subsection{Garis Horizontal}

Fitur Semantik berikutnya yang diperoleh dari Aksara Bali adalah garis horizontal. Fitur ini diperoleh dengan mencari garis horizontal yang terdapat pada Aksara Bali. Berikut ini adalah hasil fitur garis horizontal yang dihasilkan pada aksara " $k a$ ".

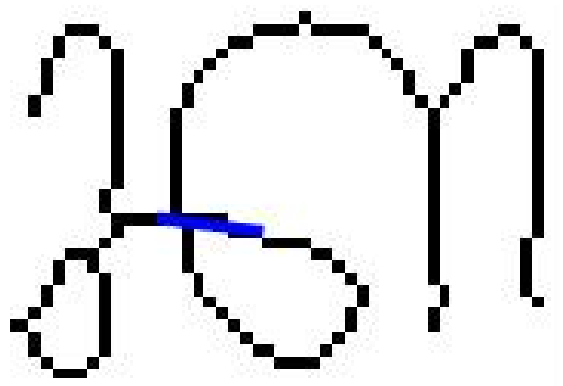

Gambar 8. Garis Horizontal Pada Aksara Bali "KA"

\section{Fitur Arah}

Selain menghasilkan fitur semantik, proses ekstraksi fitur juga menghasilkan fitur arah untuk menambah fitur yang terdapat pada masing-masing Aksara Bali. Fitur arah digunakan untuk mendapatkan nilai arah dari karakter Aksara Bali. Fitur arah diperoleh dengan ketentuan nilai arah yang terdapat pada tabel 1. Citra karakter Aksara Bali yang sudah diberikan nilai arah akan dibagi menjadi empat zona, yaitu zona kiri atas, kanan atas, kiri bawah dan kanan bawah.

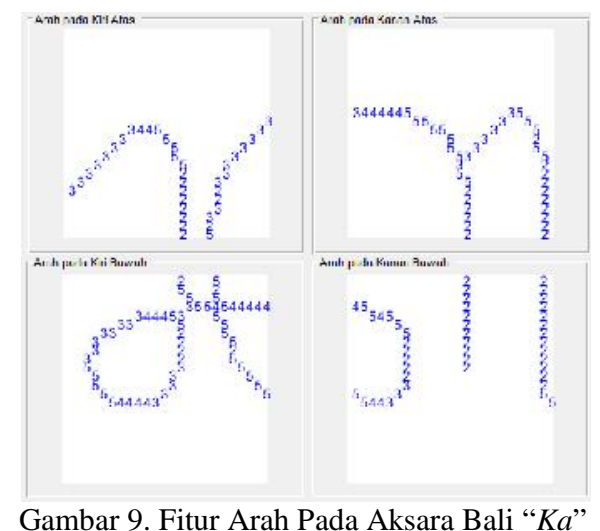

Berikut ini adalah nilai fitur arah yang diperoleh pada setiap wilayah karakter Aksara Bali.
Tabel 6. Fitur Arah Pada Aksara Bali "KA"

\begin{tabular}{|l|c|}
\hline \multicolumn{1}{|c|}{ Jenis Fitur } & Nilai Fitur \\
\hline Jumlah vertikal pada kiri atas & 11 \\
\hline Jumlah diagonal kanan pada kiri atas & 18 \\
\hline Jumlah horisontal pada kiri atas & 2 \\
\hline Jumlah diagonal kiri pada kiri atas & 6 \\
\hline Jumlah vertikal pada kanan atas & 7 \\
\hline Jumlah diagonal kanan pada kanan atas & 15 \\
\hline Jumlah horizontal pada kanan atas & 13 \\
\hline Jumlah diagonal kiri pada kanan atas & 23 \\
\hline Jumlah vertikal pada kiri bawah & 16 \\
\hline Jumlah diagonal kanan pada kiri bawah & 8 \\
\hline Jumlah horisontalpada kiri bawah & 5 \\
\hline Jumlah diagonal kiri pada kiri bawah & 15 \\
\hline Jumlah vertikal pada kanan bawah & 29 \\
\hline Jumlah diagonal kanan pada kanan bawah & 3 \\
\hline Jumlah horisontal pada kanan bawah & 4 \\
\hline Jumlah diagonal kiri pada kanan bawah & 9 \\
\hline
\end{tabular}

Nilai fitur arah ini berdasarkan jumlah fitur pada setiap wilayah untuk masing-masing jenis fitur arah. Fitur yang dihasilkan oleh setiap aksara bali tulisan tangan (handwritten) memiliki perbedaan fitur, walaupun karakter tersebut sama. Hal ini dikarenakan karakter Aksara Bali tulisan tangan tidak seperti karakter Aksara Bali cetak yang penulisannya selalu sama atau konsisten. Perbedaan penulisan lekukan aksara mungkin terjadi tergantung penulis Aksara Bali itu sendiri. Data fitur yang dihasilkan pada proses ekstraksi fitur ini selanjutnya bisa digunakan sebagai data latih (reference) pada proses pengenalan Aksara Bali.

\section{KESIMPULAN}

Berdasarkan hasil yang diperoleh, dapat disimpulkan bahwa proses ekstraksi fitur Aksara Bali menghasilkan fitur arah sebanyak 16 jenis fitur dan fitur semantik sebanyak 12 jenis fitur. Secara keseluruhan, satu karakter Aksara Bali menghasilkan 28 jenis fitur. Fitur yang dihasilkan pada setiap Aksara Bali berbeda-beda, tergantung bentuk dan penulisan karakter Aksara Bali tersebut. Data fitur ini adalah sebuah data acuan yang dapat digunakan pada proses pengenalan karakter Aksara Bali. Sebagai upaya digitalisasi Aksara Bali untuk melestarikan Aksara Bali.

\section{DAFTAR PUSTAKA}

[1] Sharma, Prakash, An Improved Zone Based Hybrid Feature Extraction Model for Handwritten Alphabets Recognition Using Euler Number, International Journal 
of Soft Computing and Engineering (IJSCE) ISSN: 2231-2307, Volume-2, Issue-2, May 2012.

[2] Ashoka H.N., Zone Based Feature Extraction and Statistical Classification Technique for Kannada Handwritten Numeral Recognition, International Journal of Computer Science \& Engineering Technology, 2012.

[3] Rajashekararadhya, S.V, Efficient Zone Based Feature Extration Algorithm For Handwritten Numeral Recognition Of Four Popular South Indian Scripts, Journal of Theoretical and Applied Information Technology, 2008.

[4] Sinha, Gita, Zone-Based Feature Extraction Techniques and SVM for Handwritten Gurmukhi Character Recognition, International Journal of Advanced Research in Computer Science and Software Engineering, Volume 2, Issue 6, ISSN: 2277 128X, 2012.

[5] Putra. IKG Darma, Pengolahan Citra Digital, Andi No ISBN 9789792914436, 2010 